\author{
Prof. dr. sc. Damir Aviani, redoviti profesor \\ Pravni fakultet Sveučilišta u Splitu
}

\title{
KONTROLA UPRAVE PUTEM PUČKOG PRAVOBRANITELJA
}

\author{
UDK: 351.941 (497.5) \\ Izvorni znantveni rad \\ Primljeno: 15. rujna 2015.
}

Ustrojstvo hrvatskog državnog i pravnog sustava obogaćeno je Ustavom Republike Hrvatske iz 1990. godine jednom novom institucijom - pučkim pravobraniteljem.

Uspostavom institucije parlamentarnog ombudsmana, Hrvatska se svrstala u široki krug zemalja koje također poznaju ovu instituciju. Uvođenje ove institucije u pravni sustav Republike Hrvatske posljedica je sve šireg nastojanja na skrbi za prava i slobode čovjeka i građanina, kao i na želji za izbjegavanjem moguće samovoljnosti nositelja javne vlasti u njihovim svakodnevnim odnosima s građanima.

Pučki je pravobranitelj, prema Ustavu Republike Hrvatske, opunomoćenik Hrvatskog sabora za promicanje i zaštitu ljudskih prava i sloboda utvrđenih Ustavom, zakonima i međunarodnim pravnim aktima o ljudskim pravima i slobodama koje je prihvatila Republika Hrvatska.

Daljnje uređenje institucije pučkog pravobranitelja obavljeno je Zakonom o pučkom pravobranitelju iz 1992. godine, koji je zamijenjen istoimenim zakonom iz 2012. godine. Ovim se Zakonom uređuju djelokrug i način rada, uvjeti za izbor i razrješenje pučkog pravobranitelja i njegovih zamjenika te suradnja s pravobraniteljem za djecu, pravobraniteljem za ravnopravnost spolova i pravobraniteljem za osobe s invaliditetom (u daljnjem tekstu: posebni pravobranitelji).

Kada se pučki pravobranitelj kao institucija, sa svojom organizacijom koju ima i funkcijama koje može ostvariti u pravnom sustavu, uspoređuje s istim ili sličnim institucijama drugih zemalja, uočava se, prvo, da je pučki pravobranitelj po svom karakteru klasičan oblik parlamentarnog ombudsmana i, drugo, da skup njegovih ovlaštenja i način na koji ih može uporabiti pokazuju kako je u hrvatskom pravnom sustavu institucija pučkog pravobranitelja ustrojena prema onim modelima parlamentarnog ombudsmana koji imaju najšire ovlasti. Ovome u prilog idu naročito dvije okolnosti: prva, prema kojoj svatko ima mogućnost da se pritužbom obrati pučkom pravobranitelju bez obzira na to ima li podnositelj pritužbe neposredni osobni pravni interes u pravnoj stvari koja je predmet pritužbe (actio popularis), i druga, što se ni za pokretanje postupka ni za njegovo vođenje ne predmnijevaju stroga pravila postupka koja bi ga eventualno mogla odugovlačiti ili pak stvarati zadršku kod onih koji se namjeravaju svojim zahtjevom obratiti toj instituciji.

\section{Ključne riječi: parlamentarni ombudsman; pučki pravobranitelj; promicanje $i$ zaštita ljudskih prava i sloboda}

\section{UVOD}

U modernim državama parlamentarnog sustava vlasti, raznim oblicima i metodama parlamentarne kontrole nad upravom pridodaje se, osobito nakon Drugoga svjetskoga rata, još jedna institucija. To je parlamentarni ombudsman, 
koji kao povjerenik parlamenta nadzire poštovanje ljudskih i građanskih prava od strane državne uprave, drugih tijela s javnim ovlastima i javnih službi. ${ }^{1}$

Jedno od temeljnih svojstava institucije ombudsmana jest ograničenost njegove kontrolne ovlasti na pravo utvrđivanja određene nezakonitosti odnosno nepravilnosti u radu nadziranih subjekata zbog koje je došlo do povrede nečijih prava. Autoritet ombudsmana proizlazi iz njegove veze s parlamentom u čije ime djeluje. To je i razlog da se kontrola koju provodi ombudsman može smatrati vidom parlamentarne kontrole nad upravom.

Prvi ombudsman ustanovljen je u Švedskoj, Ustavom iz 1809. godine, pod nazivom justitieombudsman. Zbog svojih osobina i rezultata koje postiže, poslužio je kao poticaj za uspostavljanje sličnih institucija u mnogim suvremenim pravnim sustavima. Tako je, po uzoru na švedski parlamentarni ombudsman, institucija ombudsmana uspostavljena prvo u Finskoj (1919.), a nakon Drugoga svjetskog rata i u mnogim drugim državama, ${ }^{2}$ kao i u jednoj zajednici država (ombudsman Europske unije).

Tako široko prihvaćanje ove institucije ukazuje na njezinu korisnost, kako u kontroli rada javne uprave, tako i u zaštiti ljudskih i građanskih prava, bez obzira na strukturu političkog i pravnog sustava zemlje u kojoj je prihvaćena.

Ustrojstvo hrvatskog državnog i pravnog sustava obogaćeno je Ustavom Republike Hrvatske iz 1990. godine jednom novom institucijom - pučkim pravobraniteljem.

Pučki je pravobranitelj, prema Ustavu Republike Hrvatske, ${ }^{3}$ opunomoćenik Hrvatskog sabora za promicanje i zaštitu ljudskih prava i sloboda utvrđenih Ustavom, zakonima i međunarodnim pravnim aktima o ljudskim pravima i slobodama koje je prihvatila Republika Hrvatska. Dakle, pučki pravobranitelj štiti ustavna i zakonska prava građana koja mogu biti povrijeđena uslijed nezakonitog

\footnotetext{
1 „Jednostavno, ono što je potrebno jest institucija odgovorna za probleme građana, koja može kontrolirati birokraciju bez njenog ometanja, dozvoliti neophodnu diskreciju bez dozvoljavanja kapricioznosti, nagraditi brzinu, učtivost i djelotvornost, kritizirati otezanje, neuljudnost i nedjelotvornost i osigurati pravednost otkrivajući nepravilnosti i greške.“ Reuss, H. S., Anderson, S. V.: The Ombudsman: Tribune of the People, Philadelphia, „The Annals of The American Academy of Political and Social Science“, Vol. 363, 1966., str. 48.

2 Institucija ombudsmana, prema podacima iz 1993. godine, postoji u 53 države. To su: Argentina, Australija, Austrija, Barbados, Bocvana, Cipar, Danska, Fidži, Filipini, Finska, Francuska, Gana, Gvajana, Hong Kong, Hrvatska, Indija, Irska, Island, Italija, Izrael, Jamajka, Kanada, Kostarika, Lihtenštajn, Mauricijus, Meksiko, Namibija, Nigerija, Nizozemska, Norveška, Novi Zeland, Njemačka, Pakistan, Papua Nova Gvineja, Poljska, Portugal, SAD, Senegal, Solomonski Otoci, Sudan, Svazi, Španjolska, Šri Lanka, Švedska, Švicarska, Tajvan, Tanzanija, Trinidad i Tobago, Uganda, Ujedinjeno Kraljevstvo, Zambija, Zapadna Samoa, Zimbabve. Samo u SAD-u postoji 32 ombudsmana na razini saveznih država i gradova. Vidi: Directory of Ombudsmen and International Ombudsman Offices (Revised to May 1993), Edmonton, The International Ombudsman Institute, 1993. U posljednjih nekoliko godina instituciju ombudsmana prihvatile su u svojim pravnim sustavima gotovo sve novonastale demokratske države Srednje i Istočne Europe, kao i neke druge države, tako da se broj država s institucijom ombudsmana približava brojci od 90. Vidi uvodnu riječ prof. Linde C. Reif u časopisu, The Intrernational Ombudsman Yearbook", Vol. 2, 1998., str. 1.
}

3 Ustav Republike Hrvatske (pročišćeni tekst), Narodne novine, br. 85/2010. 
ili nepravilnog rada državnih tijela, tijela lokalne i područne (regionalne) samouprave i tijela s javnim ovlastima.

Svatko može podnijeti pritužbu pučkom pravobranitelju ako smatra da su, uslijed nezakonitog ili nepravilnog rada državnih tijela, tijela lokalne i područne (regionalne) samouprave i tijela s javnim ovlastima, ugrožena ili povrijeđena njegova ustavna ili zakonska prava.

Pučkog pravobranitelja bira Hrvatski sabor na vrijeme od osam godina. Pučki pravobranitelj samostalan je i neovisan u svom radu.

Uvjeti za izbor i razrješenje pučkog pravobranitelja i njegovih zamjenika, djelokrug i način rada uređuju se zakonom. Zakonom se, radi zaštite temeljnih ustavnih prava, pučkom pravobranitelju mogu povjeriti i određene ovlasti u odnosu na pravne i fizičke osobe.

Pučki pravobranitelj i ostali opunomoćenici Hrvatskoga sabora za promicanje i zaštitu ljudskih prava i temeljnih sloboda imaju imunitet kao i zastupnici u Hrvatskom saboru. ${ }^{4}$

Bira ga Hrvatski sabor na vrijeme od osam godina, s tim što se uvjeti za izbor i razrješenje, djelokrug te način rada pučkog pravobranitelja i njegovih zamjenika uređuju zakonom.

Daljnje uređenje institucije pučkog pravobranitelja obavljeno je Zakonom o pučkom pravobranitelju iz 1992. godine, koji je zamijenjen istoimenim zakonom iz 2012. godine. ${ }^{5}$ Ovim se Zakonom uređuju djelokrug i način rada, uvjeti za izbor i razrješenje pučkog pravobranitelja i njegovih zamjenika te suradnja s pravobraniteljem za djecu, pravobraniteljem za ravnopravnost spolova i pravobraniteljem za osobe s invaliditetom (u daljnjem tekstu: posebni pravobranitelji).

Sukladno Zakonu o pučkom pravobranitelju iz 2012. godine. pučki pravobranitelj promiče i štiti ljudska prava i slobode te vladavinu prava razmatrajući pritužbe o postojanju nezakonitosti i nepravilnosti u radu državnih tijela, tijela jedinica lokalne i područne (regionalne) samouprave, pravnih osoba $\mathrm{s}$ javnim ovlastima te pravnih i fizičkih osoba u skladu s posebnim zakonima. Dakle, osnovni je zadatak pučkog pravobranitelja da razmatra pojedinačne slučajeve ugroženosti prava građana koje su im prilikom izvršavanja poslova iz svoje nadležnosti pričinila državna tijela, poglavito tijela državne uprave, tijela s javnim ovlastima ili djelatnici u tim organima ili tijelima.

Među normativnim aktima kojima se uređuje ustrojstvo pučkog pravobranitelja, treba spomenuti i poslovnik o njegovu radu, kojim se zaokružuje normativno uređenje institucije pučkog pravobranitelja. Naime, Zakonom o pučkom

\footnotetext{
4 Vidi: Ustav Republike Hrvatske, članak 93.

5 Zakon o pučkom pravobranitelju objavljen je u Narodnim novinama br. 60/92. Zamijenjen je Zakonom o pučkom pravobranitelju (Narodne novine, br 76/12.)
} 
pravobranitelju određeno je da pučki pravobranitelj donosi svoj poslovnik, s tim da taj poslovnik potvrđuje Hrvatski sabor. ${ }^{6}$

Poslovnikom se uređuju unutarnje ustrojstvo ureda pučkog pravobranitelja, način rada pučkog pravobranitelja i njegovih zamjenika, način planiranja i obavljanja poslova, metodologija izrade godišnjih i posebnih izvješća, djelokrug Savjeta za ljudska prava pučkog pravobranitelja te broj i način izbora njegovih članova i druga pitanja od važnosti za obavljanje poslova pučkog pravobranitelja.

Pučki pravobranitelj donosi Pravilnik o unutarnjem redu kojim se uređuje broj državnih službenika i namještenika potrebnih za obavljanje poslova s naznakom njihovih osnovnih poslova i zadaća i stručnih uvjeta potrebnih za njihovo obavljanje, njihove ovlasti i odgovornosti te druga pitanja od značaja za rad pučkog pravobranitelja.

Pučki pravobranitelj postaje tako jedan od subjekata demokratske, u prvom redu parlamentarne kontrole nad upravom, i svojevrsni instrument zaštite ljudskih prava i sloboda. S obzirom na ulogu koju ima u pravnom i političkom sustavu Republike Hrvatske, osobito s obzirom na djelokrug, način rada i kontrolne ovlasti kojima raspolaže, te s obzirom na odnose kako prema tijelima državne vlasti tako i prema građanima, moglo bi se kazati da institucija pučkog pravobranitelja ima sva bitna obilježja parlamentarnog ombudsmana općenito. Iz toga se razloga o pučkom pravobranitelju i može govoriti kao o hrvatskom parlamentarnom ombudsmanu.

Uspostavom institucije parlamentarnog ombudsmana, Hrvatska se svrstala u široki krug zemalja koje također poznaju ovu instituciju. Uvođenje ove institucije u pravni sustav Republike Hrvatske posljedica je sve šireg nastojanja na skrbi za prava i slobode čovjeka i građanina, kao i na želji za izbjegavanjem moguće samovoljnosti nositelja javne vlasti $\mathrm{u}$ njihovim svakodnevnim odnosima $\mathrm{s}$ građanima.

Institucionaliziranje pučkog pravobranitelja nastavljeno je izborom dr. Branka Bapca za prvog pučkog pravobranitelja Republike Hrvatske dana 2. lipnja 1993. godine.

Naravno, sama činjenica izbora određene osobe za nositelja funkcije pučkog pravobranitelja nije bila dovoljna da bi institucija kao takva mogla preuzeti i s uspjehom obavljati sve one poslove iz djelokruga svoje nadležnosti. Nužno je bilo, također, ostvariti organizacijske pretpostavke za djelovanje, kao što su prostor i odgovarajuća oprema; potrebno je bilo isto tako osigurati materijalne uvjete za rad te, konačno, kadrovski ekipirati ukupnu službu institucije do razine koja će omogućiti kvalitetu u stručnom smislu i efikasnost djelovanja u obavljanju poslova. Inače, ured pučkog pravobranitelja službeno je otvoren dana 1. siječnja 1994. godine.?

6 Prvi Poslovnik pučkog pravobranitelja donesen je 1997. godine (Narodne novine, broj 71/97). Zmijenjen je sada važećim Poslovnikom pučkog pravobranitelja (Narodne novine, broj 59/13).

7 U prvom izvješću o svom radu za 1994. godinu, upućenom Saboru na razmatranje i usvajanje, pučki pravobranitelj dr. Babac ocijenio je ustrojavanje institucije pučkog pravobranitelja i osiguranje njegova djelovanja kao jedan od veoma važnih državotvornih zadataka u izgradnji Hrvatske. Vidi: Izvješće Pučkoga pravobranitelja hrvatskog, 1994., Ured pučkog pravobranitelja, Zagreb, 1995., str. 1. 
Dr. Babac obnašao je dužnost pučkog pravobranitelja do 28. lipnja 1996. godine, kada ga je tadašnji Zastupnički dom Sabora razriješio dužnosti, prihvaćajući njegovu ostavku. ${ }^{8}$ Njegova je ostavka bila motivirana prije svega okolnošću da Sabor nije usvojio njegovo izvješće, zamjerajući mu što do podnošenja izvješća još uvijek nije bio donesen poslovnik o njegovu radu, što nije bio imenovan ni jedan od trojice pomoćnika, što je zauzeto stajalište da je izvješće manjkavo itd.

Nakon toga, tadašnji Zastupnički dom Sabora imenovao je 28. lipnja 1996. godine za drugog pučkog pravobranitelja Antu Klarića, diplomiranog pravnika i nakadašnjeg zastupnika u bivšem Zastupničkom domu Sabora, koji je stupio na dužnost danom imenovanja. ${ }^{9}$ Potom je 2004. godine za pučkog pravobranitelja imenovan Jurica Malčić, a od 2013. pučka pravobraniteljica je Lora Vidaković.

Od otvaranja ureda, pučki pravobranitelj djeluje oko dvadeset godina, i to je vrijeme, moglo bi se reći, dostatno za davanje odgovarajućih prvih ocjena djelovanja te institucije. Nužno je, međutim, pri vrednovanju institucije pučkog pravobranitelja razmotriti rezultate njegova rada, u odnosu kako prema ukupnoj nadležnosti koju mu otvara pravni sustav Republike Hrvatske, tako i prema uvjetima društvene sredine u kojoj je nastao i razvijao se.

Naime, treba imati na umu da je institucija pučkog pravobranitelja nastala u pravnom i političkom sustavu Republike Hrvatske $u$ jednom posebnom vremenu koje je karakterizirao velik broj promjena i na državno-političkom i na pravnom planu.

Nova institucija pučkog pravobranitelja morala je i mora u takvim uvjetima pronalaziti vlastite puteve kako za ostvarivanje funkcije koja joj je povjerena tako i za vlastito potvrđivanje i afirmaciju u pravnom sustavu. Iskustva drugih pravnih sustava s ovom institucijom, koja su, nema sumnje, bila dragocjena u trenutku kad se odlučivalo o uspostavi institucije pučkog pravobranitelja, u njegovim prvim praktičnim koracima teško da su mogla biti uzorom ili od veće koristi. ${ }^{10}$

8 Odluka Zastupničkog doma Sabora o imenovanju dr. Branka Bapca za pučkog pravobranitelja objavljena je, kao što je već rečeno, u Narodnim novinama br. 55/93, a odluka o njegovu razrješenju u Narodnim novinama br. 54/96.

9 Odluka Zastupničkog doma Sabora o izboru Ante Klarića za pučkog pravobranitelja objavljena je u Narodnim novinama br. 54/96.

10 Može se reći da je sudbina ljudskih prava u uskoj vezi s promjenama povijesnih potreba političkih sustava, posebice u bivšim socijalističkim zemljama. Na društvenu poziciju prava i sloboda čovjeka i građanina u tim državama utjecale su dvije suprotne pojave. Prva je prihvaćanje široke liste tih prava u ustavima, a druga je zabranjivanje postojanja i funkcioniranja političkih stranaka bitno različitih od vladajuće komunističke stranke. Ljudska su se i građanska prava mogla ostvariti jedino u ,harmoniji s interesima socijalizma", što je predstavljalo ograničenje klasičnih političkih prava. Relativno nizak društveni standard onemogućavao je kvalitetnu provedbu i ostalih prava koja su zahtijevala veća društvena ulaganja (npr. u oblastima zdravstva, obrazovanja, kulture i dr.). Na doktrinarnoj je razini takav konstitucionalni odnos prema ljudskim pravima urodio izbjegavanjem znanstvenika da pišu o toj temi. Istraživači su se uglavnom slagali s glavnom službenom linijom evolucije ljudskih prava „da je socijalistički sustav prva politička formacija gdje su ljudska prava istinski realizirana". Vidi: Földesi, T.: „The Unity of Human Rights in Western and Eastern Europe: Meditation about Human Rights“, Roma, Rivista internazionale di filosofia del diritto, IV serie - LXVII, 1990., str. 82 i dalje. Tomás Földesi dalje navodi da je ograničavanje ljudskih prava zaustavilo razvoj društva Istočne Europe, te se zalaže za prevrednovanje teorije o ljudskim pravima u tim društvima. 


\section{DJELOKRUG I POSLOVI PUČKOG PRAVOBRANITELJA}

Općenito, parlamentarni ombudsmani uspostavljaju se s osnovnim ciljem da kao neovisne institucije nadziru rad državne uprave, drugih tijela javne vlasti ili tijela kojima su povjerene javne ovlasti, te da na odgovarajući način reagiraju ako ustanove da nadzirani subjekt svojim radom povređuje odnosno ugrožava ljudska i građanska prava ili slobode.

Takva je uloga dodijeljena i pučkom pravobranitelju Republike Hrvatske.

Zbog toga se može kazati da poslovi kontrole rada državne uprave, tijela s javnim ovlastima i djelatnika u tim tijelima predstavljaju temeljne poslove iz djelokruga pučkog pravobranitelja.

Pored poslova kontrole, pučki pravobranitelj obavlja i druge poslove iz svoje nadležnosti. Tako, u području promicanja ljudskih prava i sloboda pučki pravobranitelj prati stanje i ukazuje na potrebu njihove zaštite, obavlja istraživačkoanalitičku djelatnost, razvija i održava bazu podataka i dokumentacije, pravodobno i redovito informira javnost i zainteresirane sudionike, aktivno potiče i održava suradnju s organizacijama civilnog društva, međunarodnim organizacijama i znanstvenoistraživačkim institucijama te potiče usklađivanje zakonodavstva s međunarodnim i europskim standardima i njihovu primjenu. Nadalje, pučki pravobranitelj prati usklađenost zakona i drugih propisa $s$ odredbama Ustava Republike Hrvatske i međunarodnim pravnim aktima koji su dio unutarnjeg pravnog poretka Republike Hrvatske.

Pučki pravobranitelj ima pravo podnijeti zahtjev za pokretanje postupka ocjene suglasnosti zakona s Ustavom i ocjenu suglasnosti drugih propisa te općih akata s Ustavom i zakonom.

Takve ovlasti uključuju i mogućnost iniciranja donošenja izmjena zakona u Saboru koji se odnose na zaštitu ustavnih i zakonskih prava građana, pružanja savjeta tijelima javne vlasti i građanima i dr.

\section{Poslovi kontrole pučkog pravobranitelja}

Kod kontrole nad upravom od strane pučkog pravobranitelja, jednako kao i kod svake kontrole nad upravom, možemo razlikovati predmet kontrole, subjekte kontrole i kontrolne ovlasti.

\section{a) Predmet i subjekti kontrole pučkog pravobranitelja}

Predmet i subjekti kontrole proizlaze iz opće uloge koja je Ustavom i zakonom dodijeljena pučkom pravobranitelju. U toj ulozi pučki pravobranitelj, kao što je već naglašeno, razmatra pritužbe o postojanju nezakonitosti i nepravilnosti u radu državnih tijela, tijela jedinica lokalne i područne (regionalne) samouprave, pravnih osoba s javnim ovlastima, sa svrhom da utvrdi jesu li i u kojoj mjeri navedeni subjekti u obavljanju poslova iz svoje nadležnosti ugrozili ili povrijedili pojedina prava građana. 
Predmet kontrole pučkog pravobranitelja jest izvršavanje poslova određenih subjekata iz njihovih nadležnosti kojima se može ugroziti odnosno povrijediti pravo građana. S obzirom na okolnost da se pravo može ugroziti odnosno povrijediti i činjenjem (aktivnim djelovanjem) i propuštanjem dužnog činjenja, može se kazati da je predmet kontrole pučkog pravobranitelja jednako i činjenje i propuštanje činjenja, kao i akti koje donose i mjere koje poduzimaju određeni subjekti.

U tom ozračju važno je pitanje raspolaže li pučki pravobranitelj ovlasti da razmatra i takve pojedinačne akte u kojima je sadržana slobodna (diskrecijska) ocjena.

Kao što znamo, pravni poredak dopušta, prije svega državnoj upravi, da u određenim zakonom predviđenim slučajevima odlučuje temeljem slobodne (diskrecijske) ocjene. Takvo odlučivanje temelji se onda na posebnoj alternativnoj (disjunktivnoj) pravnoj normi u okviru koje donosilac akta bira po slobodnom uvjerenju jednu od više zakonom ponuđenih alternativa. Izbor alternative je tada stvar slobodne ocjene primjenjivača prava, koji se onda pri izboru rukovodi nekim od načela oportuniteta odnosno svrhovitosti. Sadržaj diskrecijskog odlučivanja izlazi tako iz okvira legaliteta (zakonitosti) i kreće se u potpunosti u sferi oportuniteta (svrhovitosti).

Iz tih je razloga onda i kontrola akata u kojima je sadržana slobodna (diskrecijska) ocjena posebna, utoliko što takvu kontrolu (dakle, pitanje pravilnosti izbora određene alternative) mogu obavljati samo subjekti koji u funkciji kontrole imaju pravo ocjenjivati i zakonitost i svrhovitost određenog akta. Kad je u pitanju upravni akt u hrvatskom pravnom sustavu, onda je kontrola koju vrši tijelo drugog stupnja nad radom tijela prvog stupnja povodom žalbe u upravnom postupku. ${ }^{11}$

Sve ove okolnosti bitno utječu i na davanje odgovora na pitanje može li pučki pravobranitelj obavljati kontrolu i nad aktima koji su doneseni po slobodnoj ocjeni ili, drugim riječima, može li ulaziti u svrhovitost izbora određene alternative.

Odgovor na to pitanje treba promatrati u sklopu ukupnih ovlasti kojima pučki pravobranitelj raspolaže. Zaključak da bi pučki pravobranitelj mogao ispitivati svrhovitost postupanja u području diskrecijske ocjene mogao bi biti utemeljen na sljedećim okolnostima. Prvo, Zakon o pučkom pravobranitelju nigdje izrijekom ne isključuje njegovu mogućnost ulaska u pitanja diskrecijskog odlučivanja. Čak štoviše, predmet kontrole pučkog pravobranitelja zakonom je određen vrlo široko, kao ocjenjivanje ne samo zakonitosti nego i pravilnosti rada navedenih tijela. Takva široka odredba o ovlasti pučkog pravobranitelja u funkciji kontrole može onda otvoriti prostor i za ulaženje u pitanja diskrecijskog odlučivanja. Ako se u pravu diskrecijska ocjena gotovo uvijek vezuje za pravilnost, a ne samo za zakonitost rada, onda bi upravo ovakva odredba mogla biti podlogom

11 Tako npr. Zakon o općem upravnom postupku (Narodne novine, br. 47/09.) u čl. 107., st. 2. daje ovlast drugostupanjskom tijelu da u žalbenom postupku ocjenjuje svrhovitost rješenja koje je doneseno po slobodnoj ocjeni. 
pučkom pravobranitelju da u vršenju svoje kontrole ulazi u pitanja slobodnog (diskrecijskog) odlučivanja.

U svezi s tim treba ovdje imati na umu često isticanu karakteristiku djelovanja pučkog pravobranitelja, prema kojoj on nema nikakvih kasatornih ovlasti prema aktima čiju zakonitost odnosno pravilnost procjenjuje. Praktički to znači da svaki napor pučkog pravobranitelja u cilju otklanjanja uočenih nezakonitosti odnosno nepravilnosti može ostati bez odjeka, pa prema tome i bez pravnog učinka u svim onim slučajevima kad se subjekti, koje pučki pravobranitelj upozorava na uočene nezakonitosti ili nepravilnosti, ogluše na njegov apel. U tom smislu i diskrecijska ocjena može biti zaštićena i pored toga što bi pučki pravobranitelj ukazivao na njezinu nesvrhovitost.

Sljedeće je pitanje koja prava štiti pučki pravobranitelj. Pučki pravobranitelj djeluje u okviru ustavnih i zakonskih odredbi i međunarodnih pravnih akata o ljudskim pravima i slobodama koje je prihvatila Republika Hrvatska. ${ }^{12}$ Stoga se može kazati da pučki pravobranitelj ima pravo i obvezu, prvo, štititi temeljne slobode i prava čovjeka i građanina utvrđene posebnom glavom Ustava, drugo, štititi osobna prava i slobode utvrđene pojedinim zakonima, te na kraju, iako ne najmanje značajno, štititi ona osobna prava koja proizlaze iz međunarodnih pravnih akata o ljudskim pravima i slobodama, koje je prihvatila i Republika Hrvatska.

Ustav propisuje daje poštovanje prava čovjeka, između ostalih, jedno od najviših vrednota ustavnog poretka Republike Hrvatske (članak 3.). Pored toga, glavom III. Ustava Republike Hrvatske (članci 14.-70.) uređene su temeljne slobode i prava čovjeka i građanina. Prema Ustavu, građani Republike Hrvatske imaju sva prava i slobode, neovisno o rasi, boji kože, spolu, jeziku, vjeri, političkom ili drugom uvjerenju, nacionalnom ili socijalnom podrijetlu, imovini, rođenju, naobrazbi, društvenom položaju ili drugim osobinama (članak 14.). Sloboda i prava mogu se ograničiti samo zakonom da bi se zaštitili sloboda i prava drugih ljudi te pravni poredak, javni moral i zdravlje (članak 16.). Tko se ogriješi o odredbe Ustava o temeljnim slobodama i pravima čovjeka i građanina, osobno je odgovoran i ne može se opravdati višim nalogom (članak 20.). Sukladno Ustavu, razlikuju se dvije osnovne kategorije temeljnih sloboda i prava čovjeka i građanina: prva, osobne i političke slobode i prava (članci 21.-47.), i druga, gospodarska, socijalna i kulturna prava (članci 48.-70.). ${ }^{13}$ Kategoriji osobnih i političkih sloboda i prava pripadaju npr. pravo na život, nepovredivost čovjekove slobode i osobnosti, pravo slobodnog kretanja i biranja boravišta svakoga tko se zakonito nalazi na teritoriju Republike, nepovredivost doma, pravo na štovanje i pravnu zaštitu osobnog i obiteljskog života, dostojanstva, ugleda i časti, sloboda i tajnost dopisivanja, pravo

12 Vidi: članak 2., stavak 1. Zakona o pučkom pravobranitelju.

13 U teoriji upravnog prava, kao što je već rečeno, uobičajeno se ističu tri statusa u koje se grupiraju pojedine slobode i prava sa stajališta mogućnosti zadiranja državne uprave u ta prava. To su: prava negativnog statusa (pravna situacija građana u koju uprava, načelno, ne smije dirati), prava pozitivnog statusa (pravna situacija građana u kojoj građanin može zahtijevati od uprave određena djelovanja) i prava aktivnog statusa (pravo građana da sudjeluje u društvenom i političkom životu). 
na tajnost osobnih podataka, sloboda mišljenja i izražavanja misli, sloboda savjesti i vjeroispovijedi, pravo na mirno okupljanje i javni prosvjed, pravo na slobodno udruživanje, biračko pravo i dr. Kategoriji gospodarskih, socijalnih i kulturnih prava pripadaju pravo vlasništva, pravo nasljeđivanja, pravo na poduzetničku i tržišnu slobodu, pravo na rad i slobodu rada, pravo na zdravstvenu zaštitu, pravo na socijalnu sigurnost i socijalno osiguranje, sloboda znanstvenoga, kulturnoga i umjetničkoga stvaralaštva, pravo na zdrav život i zdrav okoliš i dr. Uvjeti pod kojima se mogu ostvarivati pojedina prava i slobode uređuju se posebnim zakonima, tj. onim zakonima kojima se uređuje pojedino područje društvenoga života.

No, pored ustavnih i zakonskih prava čovjeka i građanina, pučki pravobranitelj treba štititi, rečeno je, i ona osobna prava i slobode koja su utvrđena međunarodnim pravnim aktima koje je prihvatila Republika Hrvatska. Ovakvo širenje kruga prava i sloboda koje pučki pravobranitelj treba štititi (s ustavnih i zakonskih na ona koja su utvrđena u međunarodnopravnim aktima) razumljivo je s obzirom na okolnost što međunarodni ugovori, sklopljeni i potvrđeni u skladu s Ustavom i objavljeni, čine dio unutarnjeg pravnog poretka, a prema svojoj su pravnoj snazi iznad zakona. Njihove se odredbe mogu mijenjati ili ukidati samo uz uvjete i na način koji su njima utvrđeni, ili suglasno općim pravilima međunarodnog prava. Brojni su međunarodni ugovori koje je sklopila ili im se pridružila Republika Hrvatska, a kojima je uređeno ostvarivanje posebnih prava i sloboda građana. ${ }^{14}$

Subjekti čiji rad nadzire pučki pravobranitelj mogu se podijeliti u četiri kategorije. To su, prema Zakonu o pučkom pravobranitelju:

a) državna tijela,

b) tijela jedinica lokalne i područne (regionalne) samouprave,

c) pravne osobe s javnim ovlastima, te

d) pravne i fizičke osobe u skladu s posebnim zakonima.

Prva kategorija subjekata kontrole pučkog pravobranitelja jesu državna tijela. Tako široko određena kategorija "državna tijela" obuhvaća sva tijela državne vlasti (Sabor, Vlada, državna uprava, sudovi).

Najznačajnije područje djelovanja pučkog pravobranitelja jest razmatranje pritužbi na rad kako tijela državne uprave tako i na rad tijela jedinica lokalne $i$ područne (regionalne samouprave te pravnih osoba s javnim ovlastima. To je iz razloga što ta tijela imaju najviše kontakata s građanima, te donose najveći broj pojedinačnih odluka. ${ }^{15}$

14 Tako je Republika Hrvatska prihvatila npr. Konvenciju o eliminaciji diskriminacije žena, Konvenciju o pravnom položaju žena, Konvenciju o državljanstvu udane žene i druge. Vidi: Narodne novine - Međunarodni ugovori, br. 12/93.

15 Cca $90 \%$ pritužbi odnosi se na određena područja djelovanja tijela državne uprave, tijela jedinica lokalne i regionalne samouprave odnosno pravnih osoba s javnim ovlastima. Isto tako, preporuke koje daje pučki pravobranitelj kad ustanovi povredu određenih prava, prvenstveno su upućene tijelima državne uprave, a u manjoj mjeri i drugim subjektima (npr. Pravosudnoj akademiji, Hrvatskoj odvjetničkoj komori, Vladi i sl. Vidi Izvješće pučke pravobraniteljice za 2014. godinu, a i ranija izvješća (www.ombudsman.hr). 
Kad je u pitanju, međutim, rad Sabora, Vlade ili sudova, onda procjena mogućnosti pučkog pravobranitelja da ispituje i takav rad zahtijeva posebnu pozornost. Hrvatski sabor je, prema Ustavu, nositelj zakonodavne vlasti u Republici Hrvatskoj. U njegovu nadležnost ulazi, vidjeli smo, i imenovanje i razrješenje pučkog pravobranitelja, koji je i sam opunomoćenik Sabora. To su bili i razlozi zbog kojih je zakonodavac propisao da pučki pravobranitelj za svoj rad odgovara Saboru. Takav odnos između Sabora i pučkog pravobranitelja ne daje ni okvire ni mogućnost prema kojoj bi pučki pravobranitelj mogao nadzirati rad toga predstavničkog tijela.

Uloga pučkog pravobranitelja u promicanju i zaštiti ljudskih prava i sloboda otvara određenu mogućnost kontrole Sabora. Zakonom o pučkom pravobranitelju iz 2012. u čl. 6. dana je ovlast pučkom pravobranitelju da prati usklađenost zakona i drugih propisa s odredbama Ustava Republike Hrvatske i međunarodnim pravnim aktima koji su dio unutarnjeg pravnog poretka Republike Hrvatske. Pored toga, pučki pravobranitelj ima pravo podnijeti zahtjev za pokretanje postupka ocjene suglasnosti zakona s Ustavom i ocjenu suglasnosti drugih propisa te općih akata iz područja njegove nadležnosti u skladu s Ustavnim zakonom o Ustavnom sudu Republike Hrvatske i Zakonom o upravnim sporovima.

Izvan toga, pučki pravobranitelj nema drugih ovlasti kontrole Sabora. Dakle, pučki pravobranitelj ne može kontrolirati saborske zastupnike, članove administrativnih tijela Sabora, članove saborskih odbora i slično.

Slična ograničenja pučkom pravobranitelju postoje i kad se radi o nadzoru Vlade. Načelno, pučki pravobranitelj nema ovlast kontrolirati obavljanje političke funkcije Vlade i njezinih ministara. Pučki pravobranitelj može svoju pozornost posvetiti jedino pitanjima ustavnosti i zakonitosti općenormativnih akata i zakonitosti upravnih akata Vlade. U onim poslovima Vlade kod kojih se u formi upravnog akta odlučuje o pravima i obvezama, pučki pravobranitelj mogao bi zauzimati svoja stajališta o tome je li takvim aktom povrijeđeno pravo određenog građanina i u kolikoj mjeri.

Pučki pravobranitelj ima zadaću da, u osiguranju vladavine prava, nadzire i rad sudaca. Posebna je dužnost pučkog pravobranitelja, u granicama svojih ovlasti, osigurati da, pored tijela upravne vlasti, i sudovi poštuju Ustav i primjenjuju pravne propise objektivno i nepristrano, tako da temeljna prava i slobode građana ne budu povrijeđeni ni djelovanjem javne uprave ni suda. Nema sumnje da je vrlo upitna i nadležnost pučkog pravobranitelja kad je u pitanju mogućnost kontrole rada sudova. Mogućnost kontrole suda ograničena je ustavnim načelom neovisnosti sudstva, kojim se želi zaštititi sudstvo od raznih utjecaja sa strane, posebno od političkog pritiska. Zbog načela samostalnosti i neovisnosti sudbene vlasti, treba biti vrlo suzdržan u pitanjima mogućnosti pučkog pravobranitelja da razmatra eventualne ugroženosti prava građana koje bi u izvršavanju poslova iz svoje nadležnosti pričinili sudovi. Međutim, i suci moraju biti odgovorni za obavljanje javne funkcije. Stoga se i nad njihovim radom uspostavljaju različiti oblici kontrole, koji, međutim, moraju biti takvi da ne narušavaju princip sudske 
neovisnosti od političkog utjecaja. Uistinu nije uvijek lako povući liniju između poželjne vanjske kontrole sudstva i neprihvatljivog utjecaja na rad sudaca. Djelatnost pučkog pravobranitelja ne može dovesti u pitanje neovisnost suda niti njegovu samostalnost. U pravilu, pučki pravobranitelj intervenira tek kad je sudska presuda konačna. Može se očekivati da će pučki pravobranitelj intervenirati dok je sudski postupak u tijeku tek onda ako ustanovi da se neopravdano odugovlači u donošenju presude, jer se na taj način ugrožavaju prava i slobode građana. ${ }^{16}$

Pučka je pravobraniteljica zaprimila tijekom 2014. godine ukupno 339 pritužbi iz područja pravosuđa, a građani su se, prema Izvješću pučke pravobraniteljice za 2014. godinu, u najvećem broju (191) prituživali upravo zbog nezadovoljstva sudskim odlukama. Pritužbe koje su iznošene u pogledu meritornog rješavanja najvećim dijelom su motivirane nezadovoljstvom podnositelja nepovoljnim ishodom sudskih postupaka (136), ali i drugim razlozima koji ukazuju na sve učestalije i ozbiljnije zloupotrebe položaja te korupciju u pravosuđu (43). Također, ovdje valja pridodati i pritužbe koje se odnose na nepravilno obavljanje poslova pravosudne uprave (12).

U odnosu na ranije godine, broj je zaprimljenih pritužbi zbog dugotrajnosti sudskih postupaka u padu, vjerojatno i zbog toga jer su građani koristili pravo na podnošenje zahtjeva za zaštitu prava na suđenje u razumnom roku nadležnim sudovima. Pučka je pravobraniteljica tražila očitovanja predsjednika sudova u slučajevima nepotrebnog odugovlačenja sudskih postupaka, a predsjednici su sudova uglavnom u zakonskom roku dostavljali očitovanja. Prema podacima Uprave za organizaciju pravosuđa Ministarstva pravosuđa, proizlazi da je u 2014. godini ukupno zaprimljeno 1.035 novih predstavki građana na rad sudova, što je smanjenje u odnosu na 2013. godinu. Tijekom 2014. godine, u 88 je predstavki utvrđena osnovanost podnesenih pritužbi na odugovlačenje sudskog postupka odnosno na ponašanje suca ili drugog djelatnika suda prema stranci. Pravo građana na suđenje u razumnom roku bolje je zaštićeno, što dokazuje pad broja pritužbi iz tog područja. ${ }^{17}$

16 Sukladno čl. 22. Zakona o pučkom pravobranitelju, pučki pravobranitelj ne postupa u slučajevima o kojima se vodi sudski postupak, osim ako se radi o nepotrebnom odugovlačenju postupka ili očitoj zloupotrebi ovlasti. U tom slučaju može zatražiti očitovanje predsjednika nadležnog suda.

U poredbenom pravu da postoje različita rješenja u pogledu ovlasti parlamentarnog ombudsmana na kontrolu sudstva. Tako npr. u nekim pravnim sustavima (u Švedskoj, Finskoj, Poljskoj) parlamentarni ombudsmani imaju pravo na kontrolu rada sudstva. $\mathrm{S}$ druge pak strane, u brojnim zemljama (npr. $\mathrm{u}$ Danskoj, Norveškoj, Ujedinjenom Kraljevstvu, Novom Zelandu i dr.) parlamentarni ombudsman ne raspolaže takvom ovlasti.

17 Pritužbe pučkoj pravobraniteljici odnose se i na pojedine zemljišnoknjižne odjele, ukazujući na nepravilnosti u radu, korupciju, sukob interesa zemljišnoknjižnih djelatnika ili sudaca.

Zabilježen je porast zaprimljenih pritužbi na rad državnog odvjetništva u odnosu na prošlu godinu. Pritužitelji su nezadovoljni zbog nedovoljne zaštite javnih i državnih interesa te iskazuju nepovjerenje prema Glavnom državnom odvjetniku zbog nepokretanja kaznenih postupaka povodom njihovih kaznenih prijava, a upućena nam je i zamolba u kojoj se tražio nadzor nad radom državnog odvjetništva, kao i poduzimanje kaznenog progona. Budući da je državno odvjetništvo samostalno i neovisno pravosudno tijelo, njegov rad ne podliježe nikakvom preispitivanju, a pritužbe su proslijeđene na ispitivanje Glavnom državnom odvjetniku ili MP-u. 
Kad su u pitanju predstavnička tijela jedinica područne (regionalne) i lokalne samouprave, i tu je, držim, odnos između pučkog pravobranitelja i tih predstavničkih tijela poseban. Predstavnička tijela jedinica područne (regionalne) i lokalne samouprave obavljaju svoju nadležnost kao nositelji vlasti u okvirima tih jedinica temeljem slobodno izražene volje njihovih birača. Ovlaštenja koja pri tome rabe teško da bi mogla biti predmet kontrole pučkog pravobranitelja u svim onim slučajevima kad predstavničko tijelo ostvaruje svoju ustavom i zakonom propisanu ulogu. Moguće bi bilo jedino braniti tvrdnju da pučki pravobranitelj može stavljati primjedbe na sve akte predstavničkih tijela jedinica područne (regionalne) i lokalne samouprave, kako opće, tako i pojedinačne prirode (individualne akte) kojima se u pojedinačnim slučajevima odlučuje o pravima i dužnostima građana kad se smatraju ugroženima zbog načina na koji je takvim aktima odlučeno o njihovim pravima i obvezama.

Posljednja kategorija subjekata kontrole pučkog pravobranitelja jesu pravne i fizičke osobe u skladu s posebnim zakonima. Jedan od tih posebnih zakona jest npr. Zakon o suzbijanju diskriminacije. Pučka prabraniteljica u svom Izvješću za 2014. godinu navodi: "Kao što smo isticali u prethodnim izvješćima, zlostavljanje na radu ili mobing je već duže vremena prepoznat kao specifičan i, nažalost, rastući problem u području radnih odnosa, na koji se pritužuju radnici zaposleni kod poslodavaca u gospodarstvu i obrtu, javnim službama, ali i oni zaposleni u državnoj službi, svih stupnjeva obrazovanja i svih starosnih skupina."

Posebnom odredbom Zakona o pučkom pravobranitelju (članak 15.), propisano je da pučki pravobranitelj može u svako doba pregledati kazneno-popravne domove i druge ustanove u kojima se ograničava sloboda kretanja. To znači da su i takve ustanove (u kojima se, dakle, ograničava sloboda kretanja) subjekti kontrole pučkog pravobranitelja. ${ }^{18}$

\section{b) Kontrolne ovlasti pučkog pravobranitelja}

Kontrolne ovlasti pučkog pravobranitelja predstavljaju skup svih mjera koje je on ovlašten poduzeti u slučaju povrede ili ugroženosti prava građana koju mu je prilikom izvršavanja poslova iz svoje nadležnosti pričinio organ državne uprave, tijelo s javnim ovlastima ili djelatnik u tom organu odnosno tijelu.

U vršenju svojih kontrolnih ovlasti pučki pravobranitelj poduzima određene akcije da utvrdi postoji li ili ne postoji povreda određenih prava odnosno njihova ugroženost. Kada ustanovi bilo povredu tih prava ili njihovu ugroženost, i kada je do njih došlo kao posljedica ponašanja državne uprave, tijela s javnim ovlastima ili

Pučka pravobraniteljica zaprimila je i pritužbe građana zbog plaćanja visokih iznosa parničnih troškova državnom odvjetništvu, u kojima se ukazuje na činjenicu da državni odvjetnik, kada zastupa državu, ima pravo na nagradu po pravilima o odvjetničkoj tarifi Hrvatske odvjetničke komore. Vidi: Izvješće pučke pravobraniteljice za 2014. godinu.

18 Ovlast na pregledavanje ustanova s ograničenom slobodom kretanja jest tipična ovlast parlamentarnog ombudsmana. U poredbenom pregledu ustrojstva i rada parlamentarnih ombudsmana može se istaći, između ostaloga, njihovu ulogu u poboljšavanju uvjeta i standarda izdržavanja kazne zatvora. 
djelatnika u tim organima odnosno tijelima, onda u pravilu koristi svoje kontrolne ovlasti s ciljem da se zaštite povrijeđena odnosno ugrožena prava.

Zakonom o pučkom pravobranitelju određeni su uvjeti koji skupno moraju biti ispunjeni da bi pučki pravobranitelj mogao poduzeti određene akcije i mjere. To su: prvo, da je u pitanju pojedinačni slučaj ugroženosti ili povrede prava odnosno slobode građana, drugo, da se radi o izvršavanju poslova iz svoje nadležnosti od strane državnih tijela, tijela jedinica lokalne i područne (regionalne) samouprave i pravnih osoba s javnim ovlastima odnosno, u skladu s posebnim zakonima, rad pravnih i fizičkih osoba i treće, uzročno-posljedična veza između pojedinačnog slučaja ugroženosti prava građana i izvršavanja poslova iz svoje nadležnosti od strane navedenih tijela.

Zakonodavac je kod određivanja kontrolnih ovlaštenja kojima raspolaže pučki pravobranitelj, kao i kod određivanja uvjeta pod kojima se takva kontrolna ovlaštenja mogu koristiti, uporabio jednu prilagodljiviju varijantu prema kojoj za djelovanje pučkog pravobranitelja nije neophodno da uistinu dođe do povrede nečijih prava. Do njegove intervencije može doći već onda kada je određeno pravo ugroženo, odnosno čak i u onim slučajevima kada dođe u opasnost da bude povrijeđeno (to su npr. slučajevi kad se otežava ostvarivanje nekog prava odlaganjem o njegovom odlučivanju, odugovlačenjem postupka, šutnjom uprave i sl.).

Ugroženost prava građana treba biti posljedica izvršavanja poslova iz nadležnosti tijela čiji rad pučki pravobranitelj nadzire. Nije neophodno da izvršavanje poslova bude nezakonito ili nepravilno, već je dovoljno da se radi o izvršavanju poslova iz nadležnosti određenih subjekata. Isto tako, kao što je već rečeno, nije bitno u čemu se sastoji radnja kojom se ugrozilo nečije pravo, je li to aktivno djelovanje ili samo propuštanje da se dužno djelovanje obavi.

Pučki pravobranitelj upozorava, obavještava, predlaže i daje preporuke. On nema ovlaštenja kojima bi mogao izravno zahvaćati u akte ili radnje tijela čiju djelatnost nadzire. ${ }^{19}$

Ako utvrdi da se radi o povredi prava s elementima kaznenoga djela, prekršaja ili povrede radne stege, pučki pravobranitelj može predložiti pokretanje kaznenog, prekršajnog ili stegovnog postupka. On, dakle, nema pravo pokretanja kaznenog, prekršajnog ili stegovnog postupka, već samo pravo predlaganja pokretanja takvih postupaka onim subjektima koji su ovlašteni na takvo pokretanje. U tome se ovlaštenja pučkog pravobranitelja razlikuju od onih ovlaštenja kojima raspolažu parlamentarni ombudsmani npr. u Švedskoj i Finskoj.

19 „U tu svrhu pučki je pravobranitelj dužan, ovisno o okolnostima slučaja, upozoravati - npr. na nedopustivost ponašanja ili poduzimanja namjeravanog, predlagati - npr. da se ono što je po pravu, moralu i pravičnosti opravdano i poduzme, i preporučivati - npr. sa stajališta javnog interesa i zaštite prava najprikladnije načine postupanja, djelovanja ...” Iz intervjua dr. Branka Bapca u „Glasniku HDZ” od 24. lipnja 1993.; navedeno prema „Glasniku Pučkoga pravobranitelja hrvatskog”, Predbroj, Zagreb, 1995., str. 13. 
Tijelo čijom je djelatnošću, po mišljenju pučkog pravobranitelja, nastala povreda prava mora u roku koji mu odredi pučki pravobranitelj obavijestiti pučkog pravobranitelja o poduzetim mjerama povodom njegova upozorenja, prijedloga ili preporuke. Ako to tijelo ne postupi u određenom roku sukladno s traženjem pučkog pravobranitelja, ili ne postupi po njegovim preporukama, pučki pravobranitelj će o tome obavijestiti, sukladno Zakonu o pučkom pravobranitelju (čl. 27.) tijelo nadležno za provođenje nadzora nad tim tijelom.

Ako tijelo koje obavlja nadzor u za to ostavljenom roku ne izvijesti o utvrđenim činjenicama i poduzetim mjerama, pučki pravobranitelj će o tome obavijestiti Vladu Republike Hrvatske. Međutim, ako se radi o većem stupnju kršenja ili ugroženosti prava građana, ili o nepoduzimanju mjera u skladu s njegovom preporukom ili prijedlogom, pučki pravobranitelj može obavijestiti Hrvatski sabor $\mathrm{i}$ javnost.

Držim da je vrlo značajna ovlast pučkog pravobranitelja na obavještavanje Sabora i javnosti o većem stupnju ugrožavanja prava građana, odnosno o odbijanju određenog subjekta, koji je takvu ugroženost prava pričinio, da postupi u skladu s njegovim traženjem.

Čak štoviše, moglo bi se reći kako je u djelovanju pučkog pravobranitelja najznačajnija okolnost $u$ tome što on o propustima koje je uočio obavještava Sabor. Ovo zbog toga što Sabor može, temeljem obavijesti pučkog pravobranitelja, pokrenuti različite akcije i poduzeti niz mjera prema subjektima na čije je nezakonito ili nepravilno ponašanje ukazao pučki pravobranitelj u svojoj obavijesti. Težina sankcija koje Sabor može koristiti kreću se od zahtjeva za pokretanje i vođenje različitih postupaka, pa sve do postavljanja pitanja političke odgovornosti onih subjekata na čije je negativnosti u radu ukazao pučki pravobranitelj.

Obavještavanje pak javnosti ima također značajnu ulogu. Pritisak javnosti koji može biti izražen kroz različite vidove (putem tiska, sredstava javnog priopćavanja, rada političkih ili drugih tijela, zborova građana itd.) može također uvjetovati poduzimanje niza mjera prema subjektima na čiji je loš rad ukazao pučki pravobranitelj obavještavanjem javnosti. Ovo vrijedi čak i onda kad bi eventualno povodom obavijesti Sabor propustio poduzeti određene mjere.

Treba naglasiti da pučki pravobranitelj svoja upozorenja, obavještenja, prijedloge, preporuke, izvješća može objaviti u sredstvima javnog priopćavanja i u slučajevima kad je postupljeno u skladu s njegovim traženjem. Dužnost sredstava javnog priopćavanja da takvo upozorenje, obavještenje i dr. objavi, ima posebno značenje, jer se na taj način javnost upoznaje s propustima u radu određenih tijela i, s druge strane, to opet pridonosi afirmaciji institucije pučkog pravobranitelja i podizanju njegova ugleda u javnosti.

\section{Ostali poslovi pučkog pravobranitelja}

Osim što obavlja poslove ispitivanja pojedinačnog slučaja ugroženosti prava građana, kao svoju osnovnu djelatnost, pučki pravobranitelj može, a ponekad i 
mora, obavljati i neke druge poslove. Tako, pučki pravobranitelj može pokrenuti u Saboru donošenje izmjena zakona koji se odnose na zaštitu ustavnih i zakonskih prava građana. Takva ovlast pučkog pravobranitelja također je značajna. Pri podjeljivanju ovlasti pučkom pravobranitelju da može pokretati donošenje izmjena određenih zakona, zakonodavac je očito pošao od toga da pučki pravobranitelj putem svoje prakse u ispitivanju pojedinačnih slučajeva iz svakodnevnog života može lako ustanoviti manjkavosti koje bi eventualno proizlazile iz neadekvatnih onih zakonskih odredaba koje se odnose na zaštitu ustavnih i zakonskih prava građana. Takvo pravo pokretanja izmjene zakona po mome mišljenju ne znači i obvezu pripreme teksta nacrta ili prijedloga zakona, već se ovo pravo svodi isključivo na iznošenje načelnih primjedaba na postojeći tekst i davanje prijedloga s ciljem da se zakonski tekst o kojem je riječ poboljša u smislu bolje i primjerenije zaštite ustavnih i zakonskih prava građana. Naravno, uvijek o Saboru ovisi hoće li i u kojoj mjeri poticaj pučkog pravobranitelja za donošenje izmjena zakona uroditi plodom ili ne. ${ }^{20}$

Premda nije izričito propisano zakonom, pučki pravobranitelj može djelovati i kao svojevrsni savjetnik, kako onima koji svojim djelovanjima mogu povrijediti ili ugroziti prava koja ovaj pravobranitelj mora štititi, tako i građanima glede radnji koje oni moraju poduzeti radi ostvarenja i zaštite svojeg prava. Putem savjetodavne funkcije, unatoč okolnosti da njeno obavljanje nije formalizirano, pučki pravobranitelj može najizravnije ostvariti svoje preventivno djelovanje u ostvarivanju ustavnih i zakonskih prava građana, i u sprečavanju njihova ugrožavanja od strane tijela čiji rad pučki pravobranitelj ima pravo nadzirati.

Poseban odnos između pučkog pravobranitelja i Sabora uspostavljen je obvezom pučkog pravobranitelja da podnosi Saboru godišnje izvješće o svom radu. U izvješću pučki pravobranitelj objavljuje podatke do kojih je došao glede stupnja poštovanja ustavnih i zakonskih prava građana. Godišnja izvješća trebaju tako sadržavati najznačajnije slučajeve koje je pučki pravobranitelj ispitivao u izvještajnom razdoblju. Za svaki takav slučaj trebalo bi u izvješću, a po uzoru na izvješća najznačajnijih parlamentarnih ombudsmana u svijetu, objasniti razloge pritužbe odnosno razloge postupanja na vlastitu inicijativu, radnje koje je pučki pravobranitelj poduzeo u cilju ispitivanja pojedinačne povrede odnosno ugroženosti prava građana, te razloge koje je odgovarajući djelatnik iznio pravdajući svoj akt ili postupak. Pučki pravobranitelj treba u izvješću iznijeti svoje stajalište u slučaju koji je razmatrao, mjere koje je poduzeo i efekte takvih mjera. Značenje je godišnjih izvješća višestruko. Izvješćem se ukazuje na stupanj poštovanja građanskih prava od strane tijela vlasti u Republici Hrvatskoj, ukazuje se na tijela javne vlasti koja najčešće ugrožavaju građanska prava, na mjere koje je pučki pravobranitelj poduzimao i, što je najvažnije, na učinke koji su takvim mjerama postignuti.

20 Takva je ovlast pučkog pravobranitelja na davanje inicijative za izmjenu zakona inače uobičajena ovlast parlamentarnih ombudsmana, koju oni povremeno i koriste. 
Godišnja izvješća o radu pučkog pravobranitelja podnose se, kao što je rečeno, Saboru. Nema, međutim, sumnje da je sadržaj tih izvješća izuzetno zanimljiv i najširoj javnosti. Smatram stoga da bi takva godišnja izvješća trebalo na prikladan način javno objaviti, kako bi građani mogli steći uvid u stupanj ugroženosti njihovih prava do kojih dolazi djelovanjem ili propuštanjem subjekata čiji rad nadzire pučki pravobranitelj, kao i uvid u ukupan rad pučkog pravobranitelja.

Kada se radi o ugroženosti većeg stupnja u pitanjima koja su od interesa za zaštitu ustavnih i zakonskih prava, pučki pravobranitelj može o tim slučajevima, i pored godišnjeg izvješća, podnijeti izvješće Saboru i nadležnom ministarstvu.

\section{POSTUPANJE PUČKOG PRAVOBRANITELJA}

\section{Temeljna načela postupanja pučkog pravobranitelja}

U svom djelovanju pučki se pravobranitelj mora pridržavati određenih temeljnih načela, koja su svoj poseban izraz našla i u zakonskim odredbama. To su načelo zakonitosti, načelo neovisnosti i samostalnosti, te načelo pravičnosti i morala.

Načelo neovisnosti i samostalnosti izražava se u potrebi da pučki pravobranitelj djeluje neovisno o Saboru, Vladi, političkim strankama, tijelima uprave ili bilo kojem drugom subjektu, odnosno da djeluje samostalno i nepristrano. U tom smislu jasna je odredba Zakona o pučkom pravobranitelju (članak 7., stavak 1.) prema kojoj je zabranjen svaki oblik utjecaja na rad pučkog pravobranitelja. ${ }^{21}$

Načelo zakonitosti jest temeljno ustavno načelo prema kojemu je svatko dužan držati se Ustava i zakona i poštovati pravni poredak Republike (članak 5., stavak 2. Ustava Republike Hrvatske). Zakonom o pučkom pravobranitelju (članak 2., stavak 2.) određeno je da pučki pravobranitelj djeluje u okviru ustavnih i zakonskih odredbi i međunarodnih pravnih akata o ljudskim pravima i slobodama koje je prihvatila Republika Hrvatska. Ustrojstvo pučkog pravobranitelja, mjere koje poduzima i sve ostale njegove aktivnosti moraju biti u skladu s Ustavom, zakonom i drugim važećim propisima, uključujući i međunarodne pravne akte koje je prihvatila Republika Hrvatska. Načelo neovisnosti i samostalnosti pučkog pravobranitelja može se ostvariti jedino u skladu s načelom zakonitosti.

${ }_{21}$ O svojoj stranačkoj neovisnosti kao pučkog pravobranitelja, dr. Babac piše sljedeće: „Konačno, bilo je postavljeno i pitanje 'stranačke neovisnosti' osobe postojećega pučkog pravobranitelja kao zapreka ili problem u svezi s nepristranošću i samostalnošću u obavljanju svoje funkcije. Odgovoreno je na to da nije mogućim razvidjeti u čemu se tu vidi problem. Kao što se tu trebalo uzeti u obzir, a nije se tako postupalo, politički se život u nacionalnoj državi kanalizira prvenstveno kroz političke stranke, i nesumnjivim je to da osoba pučkoga pravobranitelja mora uživati legitimitet, a to znači (i) visoko povjerenje vladajuće stranke. Ono što se pri tomu ne primjećuje, jest to da je to samo legitimacija, a kada ste, dotično čim postanete državni dužnosnik, odmah morate početi djelovati po logici države i njezinih institucija. I vodim računa o izgradnji Hrvatske kao nacionalne države. A, osim toga, kako je HDZ narodna i kršćanska stranka, vjerujem da način na koji ja obavljam ovaj posao, a to je prije svega, da se vodimo vrednotama katoličke civilizacije i kulture, nije škodljiv ni interesima stranke što se javnu dužnost obavlja po logici države i vodjeno takvim vrijednostima." Izvješće Pučkoga pravobranitelja hrvatskog, 1994., op. cit., str. 41. 
Načelo pravičnosti, jednakosti i morala također je jedno od temeljnih načela kojih se u svom radu mora pridržavati pučki pravobranitelj. Naime, pučki pravobranitelj obnaša izuzetno značajnu javnu i društvenu funkciju. Obnašajući tu funkciju, on prosuđuje postoji li i u kolikoj mjeri povreda odnosno ugroženost prava pojedinca kroz djelovanje tijela javne vlasti odnosno djelatnika u tim tijelima. Sasvim je jasno da u prosudbi takvih slučajeva pučki pravobranitelj mora biti pravičan i nepristran. S druge strane, moralnost mora biti odlika pučkog pravobranitelja s obzirom na sve okolnosti koje se vezuju za funkciju koju obnaša i za njegovu osobnost.

Naravno, kategorija pravičnosti i morala povijesno je određena. Ona se oblikuje u neposrednoj vezi s uvjetima života određene društvene zajednice, kulturnom tradicijom, ideološkim i drugim predodžbama. Za očekivati je da će pučki pravobranitelj u uvjetima hrvatskog društvenog i pravnog sustava u svom svakodnevnom djelovanju iskazivati poštovanje kako načela pravičnosti tako i morala, i time se potvrđivati kao posebna i izuzetno značajna institucija koja uvažava sve osnovne društvene vrijednosti. ${ }^{22}$

\section{Ispitivanje pojedinačnih slučajeva ugroženosti prava građana}

Pučki pravobranitelj ispituje pojedinačne povrede ustavnih i zakonskih prava građana, propusta ili drugih nepravilnosti u radu državnih tijela, tijela jedinica lokalne i područne (regionalne) samouprave i pravnih osoba s javnim ovlastima odnosno u radu pravnih i fizičkih osoba, a u skladu s posebnim zakonima na svoju inicijativu ili na zahtjev građana.

Pučki pravobranitelj može na svoju inicijativu, neovisno o tome je li uložena pritužba, razmotriti pojedini slučaj i onda kada putem sredstava javnog priopćavanja (novina, radija, televizije) ili temeljem drugih izvora posumnja da je organ državne uprave ili tijelo s javnim ovlastima izvršavanjem poslova iz svoj nadležnosti ugrozio pravo određenog građanina.

Glede prava na podnošenje pritužbe pučkom pravobranitelju prihvaćen je u hrvatskom pravu liberalni švedski model „,actio popularis”. To znači da svatko ima pravo podnošenja pritužbe pučkom pravobranitelju bez obzira na to je li zbog povrede ustavnih i zakonskih prava građana neposredno oštećen. Dakle, osoba koja podnosi pritužbu pučkom pravobranitelju ne treba imati neposredni osobni pravni interes u pravnoj stvari koja je predmet pritužbe. ${ }^{23}$

22 „Institucija pučkog pravobranitelja predpostavlja i iziskuje društveni i politički prostor u kojemu vlada ideja o slobodama i pravima gradjana te, osobito, zajednicu gradjana kao prostor obće gradjanske čestitosti, savjesnosti i poštenja ili, u nas, u Hrvatskoj - tradicionalni hrvatski gradjanski moralitet kao osebujnu značajku hrvatske nacionalne prepoznatljivosti.” Iz intervjua dr. Branka Bapca u „Glasniku HDZ” od 24. lipnja 1993., a navedeno prema „Glasniku Pučkoga pravobranitelja hrvatskog”, op. cit., str. 11.

${ }^{23}$ Ako pučki pravobranitelj namjerava pokrenuti postupak na vlastitu inicijativu ili na prijedlog osobe čija prava nisu povrijeđena, za provođenje postupka potrebno je pribaviti suglasnost osobe kojoj su ustavna ili zakonska prava i slobode neposredno ugrožena ili povrijeđena, osim ako je riječ o zaštiti dobrobiti djeteta, ako je za slučaj saznao putem medija ili ako se radi o hitnom slučaju. Zakon o pučkom 
Na pritužbu pučkom pravobranitelju ne plaća se administrativna pristojba (taksa).

Pučki pravobranitelj slobodno odlučuje hoće li pritužbu uzeti u razmatranje i u kojem opsegu. Pokretanje postupka ispitivanja pojedinačnog slučaja povrede ili ugroženosti prava, dakle, ovisi isključivo o slobodnoj ocjeni pučkog pravobranitelja hoće li po pritužbi ili drugom obavještenju o ugroženosti prava postupati ili neće.

Ispitivanje pojedinačne povrede prava koje poduzima pučki pravobranitelj nije uređeno zakonom. Zbog toga se može kazati kako postoji visok stupanj slobode pučkog pravobranitelja u odlučivanju koje će radnje ispitivanja poduzeti i načina na koji će ih obaviti. Takva neformalnost postupanja pučkog pravobranitelja značajka je manje-više svih parlamentarnih ombudsmana, a ima za cilj, prije svega, postizanje što veće učinkovitosti njihova rada.

Da bi pučki pravobranitelj mogao provesti ispitivanje, zakonom je određeno da su mu dostupni svi podaci i obavijesti, da ima pravo uvida u svu dokumentaciju iz nadležnosti tijela čiju je djelatnost pučki pravobranitelj ovlašten nadzirati ovlastima pa i u one s obilježjem tajnosti. Naravno, kada u obavljanju svojih poslova pučki pravobranitelj sazna tajni podatak ili obavijest, ili kad izvrši uvid u dokumentaciju ili u akt s karakterom tajnosti, obvezan je tu tajnu čuvati i nakon prestanka službe. Propisi o čuvanju tajne na jednaki način obvezuju i zamjenike pučkog pravobranitelja te državne službenike i namještenike u Uredu pučkog pravobranitelja.

Državna tijela, tijela jedinica područne (regionalne) i lokalne samouprave tijela s javnim ovlastima i drugi nadzirani subjekti dužni su omogućiti pučkom pravobranitelju dostupnost obavijestima i u svojoj dokumentaciji i u svim aktima, i pružiti mu svaku drugu pomoć koju od njih zatraži.

Djelatnici u tim tijelima dužni su surađivati s pučkim pravobraniteljem i na njegov zahtjev podnositi izvješća i odgovarati na upite.

U obavljanju poslova iz svoga djelokruga, pučki pravobranitelj može zatražiti pomoć znanstvenika i stručnjaka sa sveučilišta, instituta i sličnih ustanova, a oni su dužni pružiti mu zatraženu pomoć u primjerenom roku.

Zakonom o pučkom pravobranitelju izrijekom je određeno da pučki pravobranitelj, u pravilu, ne postupa u stvarima o kojima je u tijeku postupak (upravni ili sudski).

Propisivanje načelnog stava da pučki pravobranitelj u pravilu ne postupa u stvarima o kojima je u tijeku upravni ili drugi postupak, bilo je, po mom sudu, motivirano prije svega razlogom da se ne udvostručuju postupci pred različitim tijelima, što bi išlo na uštrb načela učinkovitosti i ekonomičnosti rada. S druge pak strane, ovakav pristup zakonodavca bio je vjerojatno uvjetovan i okolnošću da je potrebno osigurati samostalnost u radu odgovarajućih tijela koja bi mogla biti ugrožena kada bi pučki pravobranitelj vodio istodobno postupak s tijelima državne uprave ili pak sudova, a posebno u slučaju kada bi vođenje takvog postupka bilo

pravobranitelju, čl. 20., st. 3. 
okončano zauzimanjem odgovarajućeg stava od strane pučkog pravobranitelja prije nego bi bio završen upravni ili sudski postupak.

S obzirom na to da je u pitanju pravilo koje može trpjeti izuzetke, mišljenja sam da pučki pravobranitelj mora i te kako dobro procijeniti hoće li i u kojoj mjeri postupiti u stvarima o kojima je u tijeku upravni ili drugi postupak. Ovdje upozoravam, primjera radi, na stavove Europske komisije za demokraciju, koja u Preporuci br. 1238 iz 1994. godine Europskom parlamentu u svezi sa situacijom u Bosni i Hercegovini navodi da ombudsman u Bosni i Hercegovini treba, kada je postupak pred javnopravnim tijelom u tijeku, svoje ovlaštenje da i on vodi postupak o istoj stvari koristiti vrlo mudro i više nego iznimno i, drugo, da smije upozoravati samo na stvari koje su od značenja za to da se osigura ispravnost postupanja. ${ }^{24}$

Kada pučki pravobranitelj dovrši postupak pokrenut na zahtjev građana, o poduzetom obavještava podnositelja pritužbe. Svoja stajališta o povredi odnosno ugroženosti ustavnih i zakonskih prava građana, pučki pravobranitelj dostavlja odnosnim tijelima na koje se ta stajališta odnose s upozorenjem, prijedlogom ili preporukom. To znači da su upozorenje, prijedlog ili preporuka nužni sastavni dio stajališta koje iznosi pučki pravobranitelj. Jasno je, dakle, da bi samo iznošenje primjedaba na nezakonit ili nepravilan rad bez upozorenja, prijedloga ili preporuke bilo nepotpuno. ${ }^{25}$

U slučaju da pučki pravobranitelj, nakon obavljenog pregleda kaznenopopravnog doma ili druge ustanove u kojoj je ograničena sloboda kretanja (članak 28. Zakona o pučkom pravobranitelju) bude imao primjedbe na rad te ustanove, treba napraviti izvješće koje dostavlja kako tijelu ustanove tako i tijelu koje obavlja nadzor nad tom ustanovom. Ukoliko u izvješću ima preporuka ili primjedbi, tijelo odnosne ustanove i tijelo koje nad njim obavlja nadzor obavijestit će odmah, a najkasnije u roku od 30 dana, pučkog pravobranitelja o poduzetim mjerama vezano za njegovo izvješće. Pučki pravobranitelj periodično obavještava javnost o obavljenim pregledima u posebnim izvješćima koja objavljuje na svojim internetskim stranicama.

\section{USTROJSTVO PUČKOG PRAVOBRANITELJA}

Institucija pučkog pravobranitelja, sukladno Ustavu Republike Hrvatske, ustrojena je za sada samo na državnoj (centralnoj) razini. Postoji samo pučki

\footnotetext{
24 Vidi: Projet Avis sur les aspects constitutionnels de la Recommandation 1238 (1994) de l'Assemblée Parlementaire sur la situation en Bosnie-Herzégovine, Strasbourg, Conseil de l'Europe: Commission Europeenne pour la democratie par le droit, Art. A.3. Tekst tog dokumenta na francuskom jeziku može se naći u „Glasniku Pučkoga pravobranitelja Hrvatskog”, op. cit., str. 21-25.

25 Slično stajalište zauzima npr. i Babac. On u svezi s tim piše da ,priobćivanje odluke o svojim motrištima o zaštiti prava gradjana ne bi bilo dopustivim ukoliko ne bi bilo popraćeno $\mathrm{s}$ kakvim priedlogom, preporukom ili upozorenjem". Vidi: Babac, B.: Neka razmatranja o odrazu rada pučkoga pravobranitelja na dielovanje Vlade kada s motrišta škodljivosti za gradjane procienjuje čine ili propuste javnih vlasti, op. cit., str. 13.
} 
pravobranitelj Republike Hrvatske. U ovom trenutku teško je procijeniti je li to dovoljno. Nadležnost pučkog pravobranitelja Republike Hrvatske vrlo je široka. Ona se proteže, između ostaloga, i na nadzor nad tijelima lokalne samouprave i uprave. S tog aspekta gledano, moglo bi se postaviti pitanje koliko je pučki pravobranitelj Republike Hrvatske u mogućnosti da, ustrojstvom institucije kakvu sada ima, uspješno odgovori na sve zahtjeve koji se pred instituciju postavljaju. Mišljenja sam da će vrijeme koje predstoji pokazati koliko je nužno da se u ustrojstvo institucije pučkog pravobranitelja uvode određene promjene, posebno one koje bi mogle rezultirati daljnjem razvijanju te službe na način da se ustroje pučki pravobranitelji lokalnih jedinica. S obzirom na to da je ustrojstvo institucije na samom začetku, razmišljanja o njezinu daljnjem razvijanju u ranije spomenutom smislu moglo bi uslijediti tek ako bi značajno porastao opseg posla, pogotovo kada bi na taj opseg utjecao velik broj pritužbi koje bi se odnosile na rad lokalnih tijela.

Pučkog pravobranitelja bira i razrješava dužnosti Hrvatski Sabora. ${ }^{26}$ Pučki pravobranitelj ima tri zamjenika, koje na njegov prijedlog također bira i razrješava Sabor.

Pučki pravobranitelj i njegovi zamjenici biraju se na vrijeme od osam godina i mogu biti ponovno izabrani. Dakle, trajanje mandata pučkog pravobranitelja, kao i njegovih zamjenika, vremenski se ne podudara s trajanjem mandata zastupnika u Saboru, odnosno, vremensko trajanje mandata pučkog pravobranitelja neovisno je o trajanju mandata tih zastupnika. ${ }^{27}$

Za pučkog pravobranitelja može biti izabrana ona osoba koja udovoljava sljedećim uvjetima: da je hrvatski državljanin, da ima završen integrirani preddiplomski i diplomski sveučilišni studij pravne struke (odnosno diplomirani pravnik) s najmanje 15 godina radnoga iskustva u pravnoj struci i koji se istakao u struci, i koji je osobnim zalaganjem javnosti poznat u oblasti zaštite ljudskih prava. Propisana su i dva negativna uvjeta. Naime, za pučkog pravobranitelja može biti izabrana osoba koja koja nije osuđivana i protiv koje se ne vodi kazneni postupak za kaznena djela za koja se postupak pokreće po službenoj dužnosti, i drugo, koja nije član političke stranke.

Istim ovim uvjetima trebaju udovoljavati i zamjenici pučkog pravobranitelja, s tom razlikom da moraju imati završen integrirani preddiplomski i diplomski sveučilišni studij pravne struke s najmanje osam godina radnog iskustva u struci,

26 Prije stupanja na dužnost, pučki pravobranitelj i njegovi zamjenici daju prisegu pred Hrvatskim saborom. Prisega glasi: „Prisežem da ću se u svom radu držati Ustava i zakona i poštovati pravni poredak Republike Hrvatske i da ću svoju dužnost obavljati pravično, časno i savjesno". Zakon o pučkom pravobranitelju, članak 13.

27 U poredbenom prikazu može se vidjeti da postoje različita rješenja glede odnosa trajanja mandata parlamentarnog ombudsmana i zastupnika u parlamentu, od njihovog vremenskog podudaranja (Švedska, Danska, Norveška), kada se izbor ombudsmana obavlja nakon svakih općih izbora, do vremenske neovisnosti njihovih mandata (Novi Zeland, Ujedinjeno Kraljevstvo, Poljska), kada se izbor novog ombudsmana obavlja nakon prestanka mandata starom ombudsmanu, bez obzira na mandat članova parlamenta. 
te da najmanje jedan od zamjenika pučkog pravobranitelja mora imati završen integrirani preddiplomski i diplomski sveučilišni studij pravne struke.

Pučki pravobranitelj i njegovi zamjenici mogu biti razriješeni dužnosti prije isteka vremena za koje su izabrani, ali samo u izričito propisanim slučajevima. Prema Zakonu o pučkom pravobranitelju (članak 14.), Hrvatski sabor razriješit će dužnosti pučkog pravobranitelja prije isteka vremena na koje je izabran ako to sam zatraži, ako nastupe okolnosti zbog kojih više ne ispunjava uvjete za izbor, ako je spriječen obavljati dužnost u razdoblju duljem od šest mjeseci ili ako ne obavlja dužnost sukladno Zakonu o pučkom pravobranitelju. Zamjenike pučkog pravobranitelja razrješuje Hrvatski sabor na prijedlog pučkog pravobranitelja. Hrvatski sabor razriješit će dužnosti zamjenika pučkog pravobranitelja prije isteka vremena na koje je izabran ako to sam zatraži, ako nastupe okolnosti zbog kojih više ne ispunjava uvjete za izbor zamjenika ili ako je spriječen obavljati dužnost u razdoblju duljem od šest mjeseci.

Pučki pravobranitelj ima Ured pučkog pravobranitelja kao svoju stručnu službu koja mu pomaže u izvršavanju funkcija. Ustrojstvo stručne službe, broj djelatnika, njihova zahtijevana kvalifikacija i ostali uvjeti za prijam u službu, kao i organizacija i način rada, uređuju se spomenutim poslovnikom o radu, kao internim općim pravnim aktom. Poslovnik o radu donosi pučki pravobranitelj, ali je za pravnu valjanost takvog akta potrebno da ga potvrdi Hrvatski sabor. ${ }^{28}$

U Uredu pučkog pravobranitelja ustrojavaju se unutarnje ustrojstvene jedinice za pojedina područja rada, u skladu s vrstom posla. ${ }^{29}$

Pučki pravobranitelj ima i jedno savjetodavno tijelo: Savjet za ljudska prava pučkog pravobranitelja. Zadatak mu je da razmatra i predlaže strateške smjernice u području promicanja ljudskih prava i sloboda, osigurava kontinuiranu suradnju u području ljudskih prava i sloboda između pučkog pravobranitelja, civilnog društva, akademske zajednice i medija te razmatra druga pitanja od značaja za rad pučkog pravobranitelja u području promicanja ljudskih prava i sloboda. ${ }^{30}$

28 Do sada još nije imenovan ni jedan pomoćnik pučkog pravobranitelja, a njegova služba broji šest djelatnika: predstojnik ureda, tri službenika sa zvanjem diplomiranog pravnika i dva namještenika (SSS).

29 Sukladno čl. 7. Poslovnika pučkog pravobranitelja (Narodne novine, br. 99/13.) kao unutarnje ustrojstvene jedinice nadležne za obavljanje poslova pojedinih područja rada iz djelokruga pučkog pravobranitelja, ustrojavaju se službe i to:

1. Služba za zaštitu ljudskih prava,

2. Služba za osobe lišene slobode i Nacionalni preventivni mehanizam,

3. Služba za suzbijanje diskriminacije,

4. Služba za komunikaciju, suradnju i promicanje ljudskih prava,

5. Služba za opće poslove.

30 Članove Savjeta imenuje pučki pravobranitelj na vrijeme od četiri godine iz redova predstavnika civilnog društva, nacionalnih manjina, akademske zajednice i medija. Članovi za svoj rad u Savjetu ne primaju naknadu. 
Sjedište je Ureda pučkog pravobranitelja u Zagrebu. Pučki pravobranitelj može uspostaviti područne urede izvan sjedišta Ureda. Tako su 2014. godine uspostavljena dva područna ureda: u Rijeci i u Osijeku, a očekuje se uspostavljanje područnog ureda u Splitu tijekom 2015. godine.

Sredstva za rad pučkog pravobranitelja, njegovih zamjenika i stručnih službi osiguravaju se u proračunu Republike Hrvatske. Značenje funkcije pučkog pravobranitelja dolazi do izražaja, između ostaloga, i u određivanju platnog razreda kojem pripada. Plaća pučkog pravobranitelja određuje se aktom kojim se određuju plaće i druge naknade za dužnosnike Republike Hrvatske koje bira ili imenuje predsjednik Republike, Sabor ili Vlada. Plaća pučkog pravobranitelja izjednačena je s plaćom pojedinog ministra, suca Ustavnog odnosno Vrhovnog suda, predsjednika Visokog upravnog suda. ${ }^{31}$

U Zakonu o pučkom pravobranitelju iz 1992. godine nije bilo ni jedne odredbe koja bi se odnosila na pitanje inkompatibiliteta (nespojivosti) funkcije pučkog pravobranitelja $\mathrm{s}$ drugim funkcijama odnosno poslovima. Takva odredba o inkompatibilitetu funkcije pučkog pravobranitelja našla je svoje mjesto tek u Zakonu o pučkom pravobranitelju iz 2012. godine. Sukladno čl. 8., st. 2. Zakona o pučkom pravobranitelju iz 2012. godine, pučki pravobranitelj i njegovi zamjenici ne mogu obavljati niti jednu drugu javnu ili profesionalnu dužnost niti biti članovi političke stranke.

U poredbenom prikazu institucije parlamentarnog ombudsmana, može se vidjeti da je u zakonodavstvima drugih zemalja pitanje nespojivosti funkcije parlamentarnog ombudsmana uređeno na različite načine. Ipak, moglo bi se kazati da u tim zakonodavstvima prevladavaju ona rješenja koja brane parlamentarnom ombudsmanu obavljanje drugih javnih, ali i privatnih funkcija. Načelno, s funkcijom ombudsmana, pa tako i s funkcijom pučkog pravobranitelja, ne bi trebala biti spojiva, smatramo, ni jedna funkcija, javna ili privatna, koja dovodi u pitanje nepristranost, neovisnost, samostalnost i čestitost obavljanja funkcije parlamentarnog ombudsmana. Ugrađivanje odredaba o nespojivosti funkcija pučkog pravobranitelja s drugim funkcijama odnosno poslovima u hrvatskom pravu bi, po mome mišljenju, moglo kao vrlo prihvatljivo biti preuzeto rješenje pitanja inkompatibiliteta kakvo postoji u pravu dviju skandinavskih država, Danskoj ili Norveškoj. Naime, u Danskoj i Norveškoj se zakonom načelno utvrđuje nespojivost funkcije parlamentarnog ombudsmana s drugim funkcijama, ali se ipak predviđa mogućnost da neko tijelo (npr. parlament - kao u Norveškoj ili određeni parlamentarni odbor - kao u Danskoj) odobrava parlamentarnom ombudsmanu obavljanje određene druge djelatnosti u svakom pojedinačnom slučaju. Kada bi se ovakav sustav primijenio u hrvatskom pravu, davao bi mogućnost pučkom pravobranitelju uz svoju osnovnu funkciju obavljati i neke druge poslove (kao poslove sveučilišnog profesora, savjetnika i sl.) koji ne bi

31 Koeficijent za određivanje plaće za pučkog pravobranitelja jest 10, a za njegova pomoćnika 9 . Usporedbe radi, predsjednik Ustavnog suda ima koeficijent 12, a suci toga suda 11. Jednak koeficijent imaju predsjednik i suci Vrhovnog suda (12 i 11). Koeficijent 11 ima i državni odvjetnik Republike Hrvatske. 
dovodili u pitanje niti njegovu samostalnost i nepristranost, niti bi na bilo koji način mogli utjecati na njegov ugled.

Pučki pravobranitelj i zamjenici pučkog pravobranitelja imaju imunitet kao i zastupnici u Hrvatskome saboru te se na njih na odgovarajući način primjenjuju odredbe Ustava Republike Hrvatske o imunitetu zastupnika u Hrvatskome saboru.

Pučki pravobranitelj, do stupanja na snagu Zakona o pučkom pravobranitelju iz 2012. godine, nije uživao imunitet, nije imao, dakle, pravnu zaštitu od mogućnosti pokretanja kaznenoga postupka, uhićenja i sl. koju inače uživaju zastupnici u Saboru. Ranije nepostojanje imuniteta nije dovodilo, međutim, u pitanje osobnu pravnu sigurnost i neovisnost pučkog pravobranitelja. Položaj koji ima, ovlaštenja kojima raspolaže i ugled koji uživa svojevrsna su zaštita njegove osobnosti. Oni su ujedno jamstvo savjesnog rada i moralnosti postupaka, pa je s tim u vezi posve realno očekivati njegovo djelovanje u skladu s pravnim poretkom. ${ }^{32}$

\section{ZAKLJUČNA RAZMATRANJA}

Ubi ius ibi remedium. Nema prava bez mogućnosti uporabe pravnih sredstava njegove zaštite. Drugim riječima, subjektivna prava građana uistinu malo vrijede ako, u slučaju njihova ugrožavanja ili povrede, građani nemaju stvarne mogućnosti djelotvornih pravnih sredstava za njihovu zaštitu. U tom je smislu institucija parlamentarnog ombudsmana značila pružanje građanima nove, dodatne mogućnosti zaštite njihovih prava u svim onim slučajevima kad su ta prava ugrožena ili povrijeđena djelovanjem tijela državne uprave ili drugih javnih tijela nad kojima parlamentarni ombudsman vrši nadzor.

Parlamentarni je ombudsman povjerenik parlamenta koji ispituje utemeljenost pritužbi građana na određene nezakonitosti, odnosno nepravilnosti postupanja tijela javne uprave i službenika zaposlenih u tim tijelima, i koji može povodom tih pritužbi ili samoinicijativno provoditi svojevrsni nadzor rada, prije svega tijela javne uprave i njihovih službenika. U ostvarivanju svojih ovlasti, parlamentarni ombudsman može poduzimati sve one mjere koje mu stoje na raspolaganju. Naravno, opseg tih mjera ovisan je o nizu najraznovrsnijih čimbenika. Prije svega, on je ovisan o karakteru datog društvenog i političkog sustava unutar kojega parlamentarni ombudsman ostvaruje svoju ulogu.

Ako se općenito promatra, parlamentarni ombudsman ima tri bitna svojstva: a) on je povjerenik parlamenta, te je kao institucija uspostavljen u pravilu ustavom ili zakonom, b) njegov zadatak je da na relativno neformalan način ispituje slučajeve povreda prava građana, i c) on ima ovlast konstatirati uočenu nezakonitost ili nepravilnost rada tijela nad kojima je ovlašten vršiti nadzor, i ima pravo davanja prijedloga i preporuka u svezi s mjerama koje smatra da treba poduzeti za svaki slučaj povrede individualnih prava.

32 Gledano poredbeno, postojanje imuniteta za parlamentarnog ombudsmana više je iznimka nego pravilo. Iako je, dakle, gotovo pravilo da parlamentarni ombudsmani ne uživaju imunitet, ipak se, koliko je meni poznato, nigdje protiv njih nije vodio kazneni postupak. 
Kad se povijesno promatra, prvi ombudsman uspostavljen je, kao što je dobro poznato, u Švedskoj 1809. godine. To je činjenica od koje se polazi kada se analizira institucija parlamentarnog ombudsmana od njegovih prvih početaka do danas. U toj analizi, nesumnjivo, najznačajniju ulogu igra okolnost da je parlamentarni ombudsman danas potvrđen kao jedan od najpopularnijih zaštitnika osobnih prava i sloboda građana, ne samo u Švedskoj, dakle u zemlji u kojoj je nastao, nego i u gotovo svim drugim suvremenim državama čiji se zakonodavac nadahnuo švedskim uzorom i ustanovio istu ili sličnu instituciju.

Institucija parlamentarnog ombudsmana uspostavljena je u Republici Hrvatskoj Ustavom iz 1990. godine pod nazivom pučki pravobranitelj. Njegova pojava posljedica je, prije svega, želje i napora hrvatskog ustavotvorca da i za hrvatske potrebe ustroji jedan poseban kontrolni mehanizam, koji se u svijetu već široko potvrdio, i koji je do sada dao značajne rezultate. Na taj se način hrvatski pravni sustav obogaćuje novim institucionalnim modelima koji, s jedne strane, znače širu mogućnost zaštite objektivne zakonitosti kao takve i, s druge strane, potpuniju zaštitu individualnih prava građana.

Kada se pučki pravobranitelj kao institucija, sa svojom organizacijom koju ima i funkcijama koje može ostvariti u pravnom sustavu, uspoređuje s istim ili sličnim institucijama drugih zemalja, uočava se, prvo, da je pučki pravobranitelj po svom karakteru klasičan oblik parlamentarnog ombudsmana i, drugo, da skup njegovih ovlaštenja i način na koji ih može uporabiti pokazuju kako je u hrvatskom pravnom sustavu institucija pučkog pravobranitelja ustrojena prema onim modelima parlamentarnog ombudsmana koji imaju najšire ovlasti. Ovome u prilog idu naročito dvije okolnosti: prva, prema kojoj svatko ima mogućnost da se pritužbom obrati pučkom pravobranitelju, bez obzira na to ima li podnositelj pritužbe neposredni osobni pravni interes u pravnoj stvari koja je predmet pritužbe (actio popularis) i druga, što se ni za pokretanje postupka ni za njegovo vođenje ne predmnijevaju stroga pravila postupka koja bi ga eventualno mogla odugovlačiti ili pak stvarati zadršku kod onih koji se namjeravaju svojim zahtjevom obratiti toj instituciji.

Ono što daje poseban karakter ulozi koju pučki pravobranitelj ima jest relativno složen sustav odnosa koji postoje između pučkog pravobranitelja i drugih subjekata u društvu, prije svega onih subjekata koji se nalaze u funkciji nositelja vlasti.

Tako pučki pravobranitelj ulazi u poseban sklop odnosa, prije svega s Hrvatskim saborom. Tu je njegova obveza da Saboru podnosi godišnje izvješće o svom radu, ali mu može uputiti i posebna izvješća koja se odnose na pojedinačne slučajeve, poglavito kad se radi o takvoj ugroženosti prava koja je od šireg društvenog interesa. Ova obveza, međutim, nudi mogućnost za različite pomake u odnosima između pučkog pravobranitelja i Sabora. Svojim izvješćima pučki pravobranitelj ne mora ukazivati samo na ugroženosti prava koja po prirodi funkcije mora štititi, već mu je to ujedno i mogućnost da Saboru iznese sve probleme s kojima se suočava u ostvarivanju vlastite funkcije, kao što su problemi materijalne prirode, prostora, kadrovske osposobljenosti i dr. 
Temeljem takvih izvješća, Sabor, opet, može doći do niza korisnih spoznaja koje mogu uroditi donošenjem različitih mjera, kako na planu unapređenja zaštite načela zakonitosti, tako i na planu unapređenja i razvoja pravnog sustava uopće.

S obzirom na to da se pučki pravobranitelj u svom djelovanju mora pridržavati određenih temeljnih načela, koja su svoj poseban izraz našla i u zakonskim odredbama (načelo zakonitosti, načelo pravičnosti i morala i dr.), onda je razumljivo da takvu funkciju i u hrvatskim prilikama mogu obavljati samo osobe koje svojim ukupnim stručnim i moralnim likom odgovaraju karakteru jedne takve institucije. I to je, može se reći, jedan od dokaza kako hrvatski zakonodavac, uspostavljanjem institucije pučkog pravobranitelja, nije bio motiviran samo željom za uspostavljanjem jedne nove kontrolne institucije, nego joj je pravnim propisima kojima ju je ustrojio htio također dati i onu razinu i ugled koji odgovaraju ideji na kojoj počiva institucija parlamentarnog ombudsmana u demokratskim i razvijenim pravnim sustavima.

Kada se u takvim okolnostima promatra uloga pučkog pravobranitelja i vrednuje sadržaj njegova dvadesetogodišnjega rada, onda je moguće zaključiti kako su začetak ideje o osnivanju ove institucije i početni koraci koje je ona do sada napravila dostatna podloga za mogućnost njezine afirmacije u vremenu koje dolazi.

Zakonske odredbe kojima je uređena institucija pučkog pravobranitelja pružaju, po mom mišljenju, dobru osnovu za djelotvorno ostvarivanje uloge koju inače imaju parlamentarni ombudsmani u drugim državama.

Međutim, treba imati u vidu da je institucija pučkog pravobranitelja nastala u pravnom i političkom sustavu Republike Hrvatske u jednom posebnom vremenu koje je karakterizirao veliki broj promjena i na državno-političkom i na pravnom planu. U takvim uvjetima, institucija pučkog pravobranitelja mora pronalaziti vlastite puteve, kako za ostvarivanje funkcije koja joj je povjerena, tako i za vlastito potvrđivanje u pravnom sustavu.

Proces institucionalizacije odnosno proces uklapanja pučkog pravobranitelja u društvenu sredinu na način da njegovo djelovanje bude što više u skladu s očekivanjima okoline (izraženima u zakonu), uistinu je dijakroničan fenomen. Ispravnost teze koju je postavio Huntington (1969.), naime, da je razina institucionalizacije jedne organizacije veća što organizacija duže postoji, uočava se i na primjeru pučkog pravobranitelja. Stoga možemo očekivati da će u narednom vremenu institucija pučkog pravobranitelja prebroditi početne teškoće i da će svojim stvarnim djelovanjem pridonositi boljoj zaštiti prava i sloboda čovjeka i građanina, ukoliko ona budu povrijeđena ili ugrožena djelovanjem uprave. 


\section{OMBUDSMAN IN CONTROL OF THE ADMINISTRATION}

The organization of the Croatian state and legal system enriched the Croatian Constitution of 1990, a new institution - the Ombudsman (Parliamentary protector of human rights) .

The establishment of a parliamentary ombudsman, Croatia is ranked in the wide range of countries who know that institution. The introduction of this institution in the Croatian legal system is a consequence of a wider effort to care for the rights and freedoms of human and citizen, as well as the desire to avoid the possible arbitrariness holder of public authorities in their everyday relations with citizens.

Ombudsman, under the Constitution of the Republic of Croatian is commissioner of the Croatian Parliament for the promotion and protection of human rights and freedoms enshrined in the Constitution, laws and international legal instruments on human rights and freedoms adopted by the Republic of Croatia.

Further regulation of the institution of the Ombudsman was performed first, the Ombudsman Act of 1992, which was replaced by the same name by law in 2012. This Act regulates the scope and manner of work, conditions for election and dismissal of the ombudsman and his deputies as well as cooperation with the Ombudsman for Children, the Ombudsman for Gender Equality and the Ombudsman for Persons with Disabilities.

When the Parliamentary protector of human rights, with its organization and its functions, compared with the same or similar institutions in other countries, it can be seen that the Parliamentary protector of human rights is classic form of the Parliamentary Ombudsman. Further, Croatian Parliament established Parliamentary protector of human rights under those models of parliamentary ombudsman who has the broadest powers. It is obvious in particular two circumstances: first, everyone has right to complaint to the Ombudsman, regardless of whether the complainant has direct personal legal interest in the legal matter that is the subject of the complaint (actio popularis), and second, Ombudsman can control a wide range of public bodies including courts.

\section{Key word: parliamentary ombudsman, ombudsman in Croatia human rights} and freedoms 